\begin{tabular}{|c|c|c|}
\hline $\begin{array}{l}\text { JURNAL } \\
\text { INOVASI } \\
\text { TEKNOLOGI } \\
\text { PENDIDIKAN }\end{array}$ & $\begin{array}{l}\text { Jurnal Inovasi Teknologi Pendidikan } \\
\text { Volume 5, No 1, April } 2018 \text { (12-25) } \\
\text { Online: http://journal.uny.ac.id/index.php/jitp }\end{array}$ & $\underset{\text { Ikatan Profesi Teknologi }}{\text { Pendidikan Indonesia }}$ \\
\hline
\end{tabular}

\title{
PENGEMBANGAN E-LEARNING MATA PELAJARAN GEOGRAFI UNTUK MENINGKATKAN HASIL BELAJAR PESERTA DIDIK KELAS X SMA
}

\author{
Imam Widodo ${ }^{*}$, Mukminan ${ }^{2}$ \\ 1Pusat Pendidikan dan Pelatihan Kemenristekdikti \\ 2Universitas Negeri Yogyakarta \\ ${ }^{1}$ Gedung BPPT II, Jl. MH. Thamrin No. 8 Lt. 18 Jakarta Pusat 10340, Indonesia \\ 2Jl. Colombo No. 1, Depok, Sleman 55281, Yogyakarta, Indonesia \\ * Corresponding Author. Email: imam140291@gmail.com
}

\begin{abstract}
Abstrak
Penelitian ini bertujuan untuk: (1) menghasilkan produk e-learning pada mata pelajaran Geografi bagi peserta didik kelas X SMA, (2) mengetahui kelayakan produk e-learning menurut ahli materi dan ahli media, (3) mengetahui respon peserta didik sebagai pengguna e-learning, (4) mengetahui keefektifan e-learning mata pelajaran Geografi terhadap hasil belajar kognitif peserta didik kelas X SMA, dan (5) mengetahui keefektifan e-learning mata pelajaran Geografi terhadap hasil belajar afektif khususnya kemandirian belajar peserta didik kelas X. Penelitian pengembangan ini mengacu langkah yang dikembangkan oleh Alessi \& Trollip. Prosedur pengembangan meliputi tahap perencanaan, desain, dan pengembangan. Tes beta yang dilakukan terhadap 32 peserta didik kelas X1 sebagai calon pengguna sekaligus sebagai kelas eksperimen, dan sebagai kelas kontrol X2 sebanyak 21 peserta didik. Pengumpulan data dilakukan menggunakan lembar validasi, angket kemandirian belajar, angket respon peserta didik, dan tes hasil belajar. Hasil penelitian menunjukan: Kelayakan produk e-learning masuk dalam kriteria sangat baik. Terdapat perbedaan hasil belajar antara kelas eksperimen dan kelas kontrol setelah pembelajaran. Rerata $\mathrm{N}$-gain kelas eksperimen lebih tinggi dibandingkan dengan kelas kontrol. Terdapat perbedaan kemandirian belajar antara kelas eksperimen dan kelas kontrol setelah pembelajaran. Rerata $N$-gain kelas eksperimen lebih tinggi dibandingkan dengan kelas kontrol.

Kata Kunci: e-learning, geografi, hasil belajar, kemandirian belajar
\end{abstract}

\section{DEVELOPING E-LEARNING OF GEOGRAPHY LESSON TO INCREASE LEARNING ACHIEVEMENT OF $10^{\text {th }}$ GRADE STUDENTS OF SENIOR HIGH SCHOOL}

\section{Abstract}

This research aims to: (1) produce e-learning geography lesson for 10 th grade students of Senior High School, (2) determine the feasibility of e-learning products according to subject matter experts and media experts, (3) determine the response of the learner as users of e-learning, (4) determine the effectiveness of $e$ learning in the subject of Geography on the cognitive learning achievement for $10^{\text {th }}$ grade students of Senior High School, and (5) determine the effectiveness of e-learning in the subject of geography to the affective learning in particular the self-regulated learning for $10^{\text {th }}$ grade students of Senior High School. This research is a research and development $(R \mathcal{E} D)$ and adapted from the model of Alessi $\mathcal{E}$ Trollip. The procedure includes the development of the planning, design, and development. Beta test which was conducted to 32 students class X1 as prospective users, as well as the experimental class and control class X2 as many as 21 students. Collecting data used validation sheet, questionnaire self-regulated learning, questionnaire of student's responses, and achievement test. The results of the study are: The feasibility of e-learning products is included in very good criteria. There are differences in learning achievement between the experimental class and control class after learning. The mean $N$-gain of the experimental class is higher than that of the control class. There are differences in self-regulated learning between the experimental class and control class after learning. The mean $\mathrm{N}$-gain experimental class is higher than that of the control class.

Keywords: e-learning, geography, learning achievement, self-regulated learning.

Permalink/DOI: http://dx.doi.org/10.21831/jitp.v5i1.12534

Jurnal Inovasi Teknologi Pendidikan

ISSN 2407-0963 (print) ISSN 2460-7177 (online) 


\section{Pendahuluan}

Dewasa ini teknologi informasi dan komunikasi berkembang begitu pesat, merambah ke berbagai sektor kehidupan. Situmorang mengemukakan teknologi informasi dan komunikasi bukan lagi milik orangorang tertentu, melainkan milik semua bangsa, milik semua orang dari lapisan terendah sampai teratas (Prawiradilaga, Ariani, \& Handoko, 2013, p. 16). Bahkan banyak orang tidak bisa lepas dari teknologi tersebut dalam kesehariannya, mulai dari pagi sampai petang dan sampai pagi lagi. Teknologi informasi dan komunikasi secara cepat dan revolusioner telah merubah pola pikir dan peradaban manusia.

Salah satu bidang yang memperoleh dampak dari kemajuan teknologi informasi dan komunikasi adalah bidang pendidikan. Banyak lembaga pendidikan yang menggunakan terobosan proses pembelajaran melalui teknologi informasi dan komunikasi. Dengan memanfaatkan teknologi internet, ruang dan waktu bukan lagi menjadi pembatas peserta didik untuk belajar. Materi atau bahan pembelajaran bisa didapatkan oleh pembelajar melalui berbagai sumber di internet. Perubahan pembelajaran secara konvensional yang mengutamakan metode ceramah, telah beralih menjadi sistem penyampaian bahan pembelajaran modern yang mengutamakan peran pembelajar dan pemanfaatan teknologi komputer dan internet. Pemanfaatan teknologi komputer dan internet untuk pendidikan telah melahirkan terobosan baru dalam pembelajaran yang dikenal dengan e-learning.

Konsep pembelajaran e-learning cepat sekali dikenal di luar maupun dalam negeri. Seiring dengan dikenalnya e-learning, telah lahir berbagai perangkat lunak pengolah materi ajar untuk e-learning atau Learning Management System (LMS). LMS yang yang berkembang di antaranya Author, BlackBoard Learning System, CCNet, Claroline, Desire2Learn, Dokeos, eCollege, eFont, Fedena, HotChalk, ILIAS, Moodle, dan masih banyak lagi. Di antara beberapa LMS yang berkembang, Moodle merupakan salah satu platform open source e-learning yang paling banyak digunakan, yang memungkinkan penciptaan sebuah website yang dapat diakses oleh siapa saja yang terdaftar. Platform ini memungkinkan pertukaran informasi di antara pengguna melalui mekanisme sinkron (chatting) dan komunikasi asynchronous (forum diskusi) (Costa, Alvelos, \& Teixeira, 2012, p. 335). Moodle adalah platform e-learning yang awalnya dikembangkan untuk memungkinkan pendidik membuat kursus online untuk mendorong interaksi dan konstruksi kolaboratif dengan peserta didik melalui konten pembelajaran. Hal ini memberikan peluang pendidik dari menjadi sumber pengetahuan menjadi fasilitator dan model peran dalam proses memperoleh pengetahuan dan keterampilan (Amandu, Muliira, \& Fronda, 2013, p. 677).

Sara \& Mukminan (2014, pp. 141142) mengemukakan pembelajaran e-learning merupakan pembelajaran dengan menggunakan jasa bantuan perangkat elektronik, khususnya perangkat komputer. Proses pembelajaran ini didukung oleh jasa teknologi seperti komputer, jaringan internet, dan media grafis audio visual. E-learning secara sederhana dapat dipahami sebagai suatu proses pembelajaran yang memanfaatkan teknologi informasi berupa komputer yang dilengkapi dengan sarana telekomunikasi (internet, intranet, ekstranet) dan multimedia (grafis, audio, video) sebagai media utama dalam penyampaian materi dan interaksi antara pendidik dan peserta didik. Pengembangan e-learning dilembaga pendidikan bertujuan untuk meningkatkan efektivitas dan fleksibilitas pembelajaran. Karakteristik e-learning menurut Shishkovskaya, Bakalo, \& Grigoryev (2015, p. 200) yaitu fleksibilitas, integritas, komunikasi dengan ruang yang tidak terbatas, dan dapat digunakan secara asyncronus. Hal ini dapat membuat proses pendidikan lebih efektif. Kondisi ini memungkinkan semua anggota komunitas pendidikan dapat mengorganisasi dirinya; ketersediaan sumber daya informasi; kemampuan untuk mengumpulkan, menyimpan dan berbagi informasi. 
Geografi merupakan salah satu mata pelajaran yang terdapat pada tingkat Sekolah Menengah Atas (SMA). Berdasarkan Geography Working Group's Interim Report pada tahun 1990, Geografi adalah studi dalam mempelajari hubungan antara bumi dan manusia melalui kajian tempat, ruang, dan lingkungan (Hubbard, Bartley, Fuller, \& Kitchin, 2005, p. 11). Ada tiga definisi dalam aspek kajian geografi tiga definisi yaitu studi tentang tempat yang berusaha menggambarkan dan memahami lokasi kenampakan fisik bumi dan manusia serta proses, sistem, dan keterkaitan yang tercipta oleh kenampakan-kenampakan tersebut; sebuah studi mengenai ruang yang berusaha mencari hubungan antara tempat dan pola yang timbul dari aktivitas manusia dalam membuat tatanan fisik tempat dimana mereka hidup dan bekerja; dan studi tentang lingkungan yang meliputi kedua dimensi, yaitu fisik dan manusia.

Ruang lingkup geografi dalam pembelajaran di sekolah adalah lingkungan yang merupakan sumber daya bagi kehidupan, sebaran variasi kehidupan manusia, hubungan timbal balik antara manusia dengan lingkungannya yang dapat memberikan keragaman karakter muka bumi, kesatuan regional yang merupakan perpaduan antarruang (udara, air, dan darat). Pelaksanaan pembelajaran geografi di sekolah bertujuan agar peserta didik dapat memiliki kemampuan sebagai berikut: memahami pola spasial, lingkungan dan kewilayahan serta proses yang berkaitan, menguasai keterampilan dasar dalam memperoleh data dan informasi, mengkomunikasikan dan menerapkan pengetahuan geografi; dan menampilkan perilaku peduli terhadap lingkungan hidup dan memanfaatkan sumber daya alam secara arif serta memiliki toleransi terhadap keragaman budaya masyarakat (BSNP, 2006, p. 197).

Objek studi geografi terdiri dari lima yaitu atmosfer, biosfer, hidrosfer, litosfer, dan antroposfer. Secara umum objek studi atau materi geografi memiliki tingkatan kesulitan yang tinggi, oleh sebab itu perlu banyak usaha dalam menyajikan materi tersebut kepada peserta didik. Salah satu materi yang menjadi poin penting dalam pembelajaran geografi ialah mitigasi dan adaptasi bencana alam. Materi mitigasi dan adaptasi bencana alam penting untuk dipelajari dikarenakan Indonesia merupakan negara yang rentan terjadi bencana alam yang diakibatkan karena lokasi geografis Indonesia maupun akibat faktor manusianya. Pembelajaran pada materi mitigasi dan adaptasi bencana alam harus mampu membawa gambaran materi tersebut ke dalam sebuah proses pembelajaran, baik berupa sampel (contoh) maupun tayangan (gambar atau video).

Keterkaitan materi dengan kondisi geografis Indonesia mengharuskan materi ini mudah diakses dan dipelajari kapanpun dan dimanapun dengan memanfaatkan teknologi internet dalam bentuk website. Disamping itu dengan bantuan internet, materi mitigasi dan adaptasi bencana alam bisa dengan mudah diakses tanpa dibatasi ruang dan waktu.

Pembelajaran geografi materi mitigasi dan adaptasi bencana alam di sekolah dipelajari pada jenjang SMA kelas $X$ tepatnya pada semester genap. Permasalahan yang dihadapi pada pembelajaran di akhir semester genap adalah minimnya waktu pembelajaran dikarenakan berbagai hal, misalnya ujian nasional kelas XII. Hal itu terjadi pada materi mitigasi dan adaptasi bencana alam di kelas X. Kajian matari yang luas dan waktu pertemuan tatap muka yang terbatas mengakibatkan adanya materi yang belum tuntas dipelajari.

Permasalahan yang disebutkan terjadi pada Sekolah Menengah Atas (SMA) Assalam Sukoharjo. SMA Assalam Sukoharjo merupakan sekolah yang sudah menggunakan kurikulum 2013. Berdasarkan hasil wawancara dengan pendidik geografi kelas X yang dilakukan pada 11 April 2016, pembelajaran di akhir semester genap memiliki beberapa masalah khususnya di kelas $X$ dan XI karena adanya UAN dan beberapa kegiatan sekolah lain. SMA Assalam Sukoharjo merupakan sekolah sekaligus pondok pesantren modern sehingga memiliki ke- 
giatan yang relatif lebih banyak dibandingkan sekolah formal pada umumnya. Selain ujian nasional, kegiatan lain yang ada di SMA Assalam Sukoharjo adalah ujian kepondokan yang dihadapi oleh seluruh peserta didik yang tentunya memerlukan waktu persiapan dan bias mengganggu kegiatan pembelajaran formal.

Permasalahan banyaknya kegiatan yang ada di SMA Assalam Sukoharjo tentunya berdampak terhadap kegiatan pembelajaran peserta didik. Pelaksanaan pembelajaran geografi khususnya di kelas $X$ dalam materi mitigasi dan adaptasi bencana alam menjadi terganggu. Waktu pembelajaran yang seharusnya lima kali pertemuan tersita menjadi tiga kali pertemuan dikarenakan terkendala persiapan ujian nasional kelas XII. Waktu pembelajaran geografi di kelas $\mathrm{X}$ yang relatif singkat yaitu satu jam pembelajaran per pertemuannya juga dikeluhkan oleh pendidik. Pendidik kesulitan memberikan materi pembelajaran mitigasi dan adaptasi secara maksimal.

Masalah lain yang disebutkan oleh pendidik adalah kurangnya inisiatif atau kemandirian belajar peserta didik untuk mencari bahan pembelajaran tambahan materi mitigasi dan adaptasi bencana alam dengan bantuan internet dengan gadget atau perangkat laptop yang dimilikinya. Peserta didik cenderung pasif menunggu materi yang diberikan oleh pendidik. Hal ini juga dipengaruhi belum adanya media pembelajaran e-learning di SMA Assalam Sukoharjo yang bisa memfasilitasi pembelajaran peserta didik di dunia maya. Pendidik menambahkan membutuhkan suatu portal e-learning yang bisa menyediakan materi pembelajaran dan memfasilitasi belajar peserta didik untuk lebih mandiri tanpa harus bertatap muka.

Dari hasil wawancara dengan beberapa peserta didik kelas X dan XI di SMA Assalam Sukoharjo pada tanggal 11 April 2016, mayoritas peserta didik menyukai media pembelajaran yang memiliki gambargambar dan video untuk pembelajaran geografi dikarenakan peserta didik membutuhkan gambaran nyata dari materi yang di pelajari. Beberapa peserta didik kelas XI yang diwawancarai menyebutkan bahwa mereka mendapatkan materi pembelajaran mitigasi dan adaptasi bencana alam di kelas $X$ dengan tidak maksimal karena kendala minimnya waktu pembelajaran. Pendidik hanya melaksanakan tiga kali pertemuan dengan penjelasan materi yang cukup banyak dan dengan minimnya media penunjang seperti gambar dan video untuk materi yang membutuhkan contoh nyata.

Masalah lain yang dihadapi peserta didik adalah kurangnya minat peserta didik dalam mengakses situs-situs internet yang berkaitan dengan pembelajaran. Beberapa peserta didik yang di wawancarai mengaku kurang berminat dalam mencari sumber belajar dari internet. Dalam menggunakan internet di dalam lingkungan sekolah maupun di luar lingkungan sekolah, peserta didik cenderung menyukai membuka situssitus jejaring sosial maupun situs lainnya yang dianggap menarik oleh peserta didik. Beberapa peserta didik juga mengakui kesulitan mencari bahan belajar dari internet yang baik menurut peserta didik. Biasanya jika peserta didik mencari bahan tugas dari pendidik, peserta didik memperoleh bahan yang berasal dari blog-blog pribadi. Hal itu terkadang dianggap tidak valid oleh pendidik, sedangkan peserta didik sendiri belum mengerti dan sulit untuk mencari situs-situs internet yang dianggap valid oleh pendidik.

Pemanfaatan fasilitas laboratorium komputer dan jaringan internet belum dilaksanakan secara optimal oleh pihak SMA Assalam Sukoharjo. Daya dukung fasilitas sekolah sudah cukup memadai seperti listrik, komputer, jaringan internet, serta bekal keahlian peserta didik dalam mengakses intenet belum sejalan dengan pemanfaatannya dalam proses pembelajaran. Berdasarkan angket analisis kebutuhan yang diisi oleh staf laboratorium komputer SMA Assalam Sukoharjo diperoleh informasi bahwa sekolah memiliki 3 laboratorium komputer yang terdiri dari 2 laboratorium multimedia dan 1 laboratorium bahasa. Laboratorium multimedia memiliki 40 unit komputer dengan spesifikasi 20 komputer 
prosesor intel core i5 dengan RAM 4GB dan 20 komputer prosesor intel core i3 dengan RAM 2GB. Jaringan internet yang dimiliki SMA Assalam Sukoharjo memiliki bandwidth 100 Mbps. Website dan domain khusus yang dimiliki sekolah hanya dimanfaatkan untuk kepentingan administrasi sekolah dan belum dimanfaatkan untuk mendukung kegiatan pembelajaran. Laboratorium komputer digunakan hanya untuk kegiatan pembelajaran TIK saja sehingga mata pelajaran lain belum terakomodir. Peserta didik sebetulnya sudah dibekali dengan keahlian dalam penggunaan komputer dan internet tetapi pemanfaatannya masih terbatas pada pembelajaran TIK. Hal tersebut tentu beralasan karena memang belum ada media yang berupa e-learning yang dapat mengakomodasi kegiatan pembelajaran geografi.

Permasalahan-permasalahan tersebut merupakan tugas yang harus dipecahkan oleh teknolog pembelajaran agar peserta didik dapat terfasilitasi belajarnya. Hal ini sejalan dengan definisi teknologi pembelajaran menurut AECT 1994 yaitu teori dan praktik dalam desain, pengembangan, pemanfaatan, pengelolaan, serta evaluasi proses dan sumber untuk belajar (Seels \& Richey, 1994, p. 1). Teknologi pembelajaran menurut Januszewski \& Molenda (2008, p. 1) adalah sebuah studi dan praktik untuk memudahkan pembelajaran dan meningkatkan hasil belajar dengan kegiatan membuat, menggunakan, dan mengelola proses serta sumber daya teknologi secara tepat. Dari dua definisi teknologi pembelajaran tersebut, dapat ditarik kesimpulan bahwa teknologi pembelajaran merupakan teori dan praktik desain, pengembangan, pemanfaatan, dan pengelolaan yang bertujuan untuk meningkatkan hasil belajar peserta didik.

Berdasarkan permasalahan yang telah diuraikan serta belandaskan definisi teknologi pembelajaran tersebut, Peneliti tertarik melakukan penelitian mengenai "Pengembangan e-learning Mata Pelajaran Geografi untuk Meningkatkan Hasil Belajar Peserta Didik Kelas X SMA". Pengembang- an e-learning adalah langkah awal untuk menciptakan sumber belajar bagi peserta didik guna meningkatkan kualitas pembelajaran. Dengan menggunakan e-learning, diharapkan pendidik dapat memberikan sumber belajar yang dianggap valid dengan cara memberikan situs-situs pembelajaran ataupun sumber belajar lain yang diunggah dalam portal e-learning.

Tujuan pengembangan dalam penelitian ini adalah: (1) menghasilkan produk elearning pada mata pelajaran Geografi bagi peserta didik kelas X SMA, (2) mengetahui kelayakan produk e-learning menurut ahli materi dan ahli media, (3) mengetahui respon peserta didik sebagai pengguna $e$ learning, (4) mengetahui keefektifan e-learning mata pelajaran Geografi terhadap hasil belajar kognitif peserta didik kelas X SMA, dan (5) mengetahui keefektifan e-learning mata pelajaran Geografi terhadap hasil belajar afektif khususnya kemandirian belajar peserta didik kelas $X$.

\section{Metode Penelitian}

Penelitian ini adalah penelitian pengembangan (Research and Development), yang menghasilkan sebuah produk berupa e-learning pada mata pelajaran Geografi untuk peserta didik kelas X SMA. Model pengembangan ini yang digunakan oleh peneliti mengadopsi model pengembangan dan desain pengembangan yang dikembangkan oleh Alessi \& Trollip (2001).

Model pengembangan ini memiliki tiga atribut dan tiga fase, tiga fase tersebut meliputi standard, ongoing evaluation, dan project management. Sedangkan tiga fase meliputi perencanaan (planning), desain (design) dan pengembangan (development).

Prosedur pengembangan e-learning mata pelajaran Geografi kelas X SMA Assalam Sukoharjo, diadaptasi dari prosedur pengembangan Alessi dan Trollip. Sebelum melakukan pengembangan untuk menentukan karakteristik materi dan karakteristik pengguna, peneliti telah melakukan analisis kebutuhan terlebih dahulu. Proses pengembangan e-learning pada mata pelajaran Geo- 
grafi bagi peserta didik kelas X SMA, bisa dilihat pada Gambar 1.

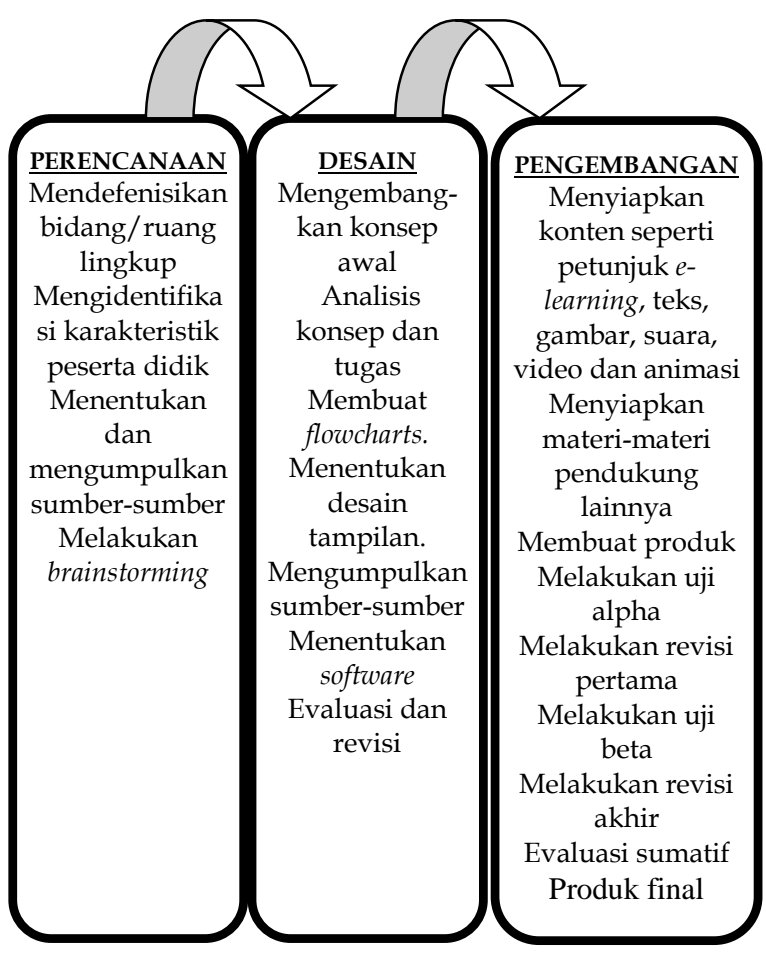

Gambar 1. Langkah-langkah Pengembangan e-learning

Dalam penelitian dan pengembangan ini, data yang terkumpul digunakan sebagai dasar untuk menentukan kelayakan produk e-learning yang dihasilkan. Data yang didapat dari hasil uji alpa dan uji beta digunakan untuk memperbaiki produk $e$ learning yang dihasilkan. Melalui uji alpha, produk e-learning yang dikembangkan divalidasi oleh ahli materi dan ahli media, sedangkan melalui uji beta produk e-learning yang dikembangkan dinilai oleh peserta didik sebagai subjek penelitian sehingga produk e-learning benar-benar telah teruji secara empiris tidak hanya secara teoritis.

Desain uji coba e-learning berdasarkan model Alessi \& Trollip meliputi tiga tahap yaitu uji alpha, uji beta, dan uji produk. Selama proses pengembangan produk dilakukan ongoing evaluation.

Uji alpha produk yaitu evaluasi oleh ahli media dan ahli materi. Uji alpha dilakukan untuk mengidentifikasi dan mengeliminasi kekurangan yang ada pada produk, kesesuaian dengan tujuan (goals), dan alur komunikasi. Data hasil uji alpha akan digunakan sebagai dasar melakukan revisi pertama terhadap produk dilakukan oleh dua ahli materi dan dua ahli media.

Kekurangan yang ditemukan pada uji alpha digunakan untuk melakukan revisi pertama, sampai pada tahap produk siap dipakai oleh peserta didik pada saat uji beta.

Uji beta merupakan hasil dari revisi yang sudah dilaksanakan pada uji alpha. Pada tahap uji beta ini produk akan diujicobakan ke beberapa peserta didik kelas $X$ yang dipilih secara acak dan tediri dari 32 orang peserta didik untuk kemudian dilakukan penilaian terhadap produk. Apabila ada kekurangan akan diperbaiki dan disempurnakan. Hasil revisi ini merupakan produk akhir.

Evaluasi sumatif menjadi rangkaian final dari produk e-learning. Pada evaluasi sumatif peserta didik menggunakan produk dan melakukan penilaian dengan tes yang sudah tersedia di e-learning. Hasil tes yang dilaksanakan menggunakan e-learning akan dibandingkan dengan pretest yang dilakukan pada evaluasi formatif pada uji alpha sebagai efektifitas dari produk yang dikembangkan.

Subjek atau responden yang terlibat dalam penelitian ini adalah peserta didik kelas X SMA Assalam Sukoharjo. Penetapan subjek berdasarkan pertimbangan bahwa materi yang diajarkan sesuai dengan analisis kebutuhan dan pelajaran pada semester II. Subjek untuk analisis kebutuhan yang terdiri dari 20 orang peserta didik kelas $X$ SMA Assalam Sukoharjo dengan pertimbangan bahwa kelas tersebut masih memperoleh nilai di bawah rata-rata yang sudah ditetapkan sekolah dan kelas lainnya. Subjek untuk uji coba test alpha dilakukan oleh ahli media dan Media yang terdiri dari 2 Ahli Materi dan 2 Ahli Media dengan dasar pertimbangan bahwa Ahli media dan materi tidak berkeberatan, berkompeten dibidangnya dan bersedia menilai instrumen. Subjek uji coba tes beta dilakukan oleh 32 orang peserta didik kelas X SMA Assalam Sukoharjo yang dipilih secara acak dengan dasar pertimbangan tidak mengganggu pro- 
ses pembelajaran dan bersedia dalam menguji produk. Subjek dalam penilaian sumatif (produk final) melibatkan 32 orang peserta didik kelas X SMA Assalam Sukoharjo yang dipilih dengan dasar pertimbangan tidak mengganggu proses pembelajaran.

Data yang diperoleh dalam penelitian ini merupakan data kualitatif dan kuantitatif. Data kualitatif didapat dari penelitian kualitas produk e-learning yang digunakan untuk kepentingan pengembangan produk. Data kuantitatif didapat dari ahli media dan ahli materi (uji alpha) juga dari peserta didik (uji beta). Data tersebut dibutuhkan agar nantinya dapat menggambarkan kelayakan e-learning dan kualitas teknik tampilan produk serta peningkatan pemahaman peserta didik setelah menggunakan produk media pembelajaran ini.

Instrumen utama yang digunakan untuk memperoleh data pokok sesuai tujuan utama penelitian ini adalah instrument kuesioner dan tes hasil belajar. Instrumen kuesioner diberikan kepada ahli media, materi, dan peserta didik (uji beta dan produk). Data tersebut akan menggambarkan secara rinci kualitas produk e-learning serta materi dari segi materi dan media yang divalidasi oleh ahli materi, ahli media, dan peserta didik. Kuesioner diberikan dalam bentuk checklist untuk mempermudah pengisiannya. Data yang dihasilkan berupa data kuantitatif yang dikotomi sehingga mudah menganalisisnya. Kuesioner untuk ahli materi meliputi lima aspek dan 27 butir indikator. Kuesioner untuk ahli media meliputi 10 aspek dan 38 butir indikator. Kuesioner tanggapan pengguna dinilai berdasarkan aspek pembelajaran, materi, dan media meliputi 10 indikator yang masing-masing terdiri atas 1 butir pertanyaan. Instrumen kemandirian belajar terdiri dari 6 indikator yang berisi 20 butir pertanyaan.

Data yang diperoleh dari validasi ahli materi dan ahli media (uji alpha) dan respon pengguna e-learning (uji beta) dianalisis menggunakan statistik deskriptif kemudian dikonversi ke dalam data " 5 " yang ditulis dalam Tabel 1.
Tabel 1. Kriteria Penilaian Berskala 5

\begin{tabular}{ccc}
\hline No. & Nilai & Kategori \\
\hline 1 & $X>4,0$ & Sangat Baik \\
2 & $3,34<X \leq X i+4,0$ & Baik \\
3 & $2,26<X \leq X i+3,34$ & Cukup \\
4 & $1,99<X \leq 2,26$ & Kurang \\
5 & $X \leq 1,99$ & Sangat Kurang \\
\hline
\end{tabular}

Sumber: Adopsi dari (Sudijono, 2013, p. 329)

Pengukuran skor tes dilakukan untuk mengukur hasil belajar peserta didik terhadap materi pebelajaran menurut ranah kognitif. Analisis data dilakukan dengan melakukan pengujian hipotesis dari hasil eksperimen berdasarkan uji coba yang telah dilakukan.

Data yang digunakan dalam menguji hipotesis ini adalah skor $N$-gain kelompok eksperimen dan kelompok kontrol. Menurut Hake (Meltzer, 2012, p. 1261), N-gain atau normalized gain adalah perbandingan gain rata-rata sebenarnya dengan gain ratarata maksimum. Persamaan yang digunakan untuk $N$-gain adalah sebagai berikut:

$$
N \text {-gain }(\mathrm{g})=\frac{\text { skor akhir-skor awal }}{\text { skor maksimum-skor awal }}
$$

Hasil perhitungan $\mathrm{N}$-gain yang diperoleh kemudian dimasukkan ke dalam klasifikasi kriteria $N$-gain seperti pada Tabel 2.

Tabel 2. Kategori Tingkat N-gain

\begin{tabular}{cc}
\hline$N$-gain & Kategori \\
\hline $\mathrm{g}<0,3$ & Rendah \\
$0,3 \leq \mathrm{g} \leq 0,7$ & Sedang \\
$\mathrm{g}>0,7$ & Tinggi \\
\hline Sumber: Sari \& Apriani & $(2014$, p. 138)
\end{tabular}

Sebelum melakukan analisis lebh lanjut, terdapat persyaratan analisis yaitu uji normalitas dan uji homogenitas. Kegiatan selanjutnya adalah data yang telah diuji normalitas dan homogenitasnya dianalisis menggunakan independent sample $t$ test pada SPSS yang selanjutnya diuji signifikansinya dengan menggunakan taraf kesalahan sebesar $5 \%$. 
Pengukuran skor kemandirian dilakukan untuk mengukur peningkatan kemandirian belajar dilakukan dengan melakukan pengujian hipotesis dari hasil eksperimen berdasarkan uji coba yang telah dilakukan. Langkah-langkah yang dilakukan adalah sama dengan langkah-langkah dalam menentukan analisis data belajar peserta didik. Sebelumnya dilakukan pengujian normalitas dan homogenitas data kemandirian belajar pada kelas eksperimen dan kelas kontrol. Data yang digunakan dalam menguji hipotesis ini adalah skor $\mathrm{N}$ gain kelompok eksperimen dan kelompok kontrol dengan rumus seperti yang telah dikemukakan sebelumnya. Hasil perhitungan $N$-gain yang diperoleh kemudian dimasukkan ke dalam klasifikasi kriteria $N$-gain seperti pada Tabel 2.

Kegiatan selanjutnya adalah data yang telah diuji normalitas dan homogenitasnya dianalisis menggunakan independent sample t test pada SPSS yang selanjutnya diuji signifikansinya dengan menggunakan taraf kesalahan sebesar 5\%.

\section{Hasil dan Pembahasan}

\section{Hasil Validasi Produk}

Kegiatan uji coba meliputi uji alpha dan uji beta. Uji alpha dilakukan oleh 2 orang ahli media dan 2 orang ahli ateri. Sedangkan pada uji beta dilakukan oleh 32 orang peserta didik kelas X1 yang mewakili calon pengguna e-learning yaitu peserta didik kelas X SMA Assalam Sukoharjo. Kelas X1 dipilih sebagai peserta uji beta setelah dilakukan brainstorming dengan pendidik mata pelajaran Geografi yang bersangkutan.

Ahli media melakukan evaluasi $e$ learning dari aspek media dan ahli materi melakukan evaluasi dari aspek materi dan isi. Hasil evaluasi ahli media dan ahli materi akan dijadikan bahan untuk melakukan revisi e-learning. Setelah dilakukan revisi terhadap hasil evaluasi uji alpha, selajutnya akan dilakukan uji beta. Hasil uji beta dijadikan bahan revisi untuk memperoleh $e$ learning yang dikategorikan layak untuk digunakan dalam pembelajaran.
Validasi materi dilakukan terhadap komponen penunjang materi yang meliputi rencana peaksanaan pembelajaran (RPP), lembar tes hasil belajar, dan konten e-learning. Pada materi e-learning terdapat 5 aspek yang dinilai oleh 2 ahli materi dalam uji alpha yang keseluruhannya memiliki 27 indikator. Kedua ahli materi memberikan saran dan komentar serta rekomendasi untuk perbaikan. Penilaian ahli materi ditunjukkan pada Tabel 3.

Tabel 3. Rerata Skor Hasil Validasi Ahli Materi

\begin{tabular}{clcccl}
\hline No & Aspek & \multicolumn{2}{c}{ Ahli Materi } & Rerata & Kriteria \\
\cline { 3 - 4 } & & \multicolumn{1}{c}{2} & & \\
\hline 1 & $\begin{array}{l}\text { Desain } \\
\text { Pembelajaran }\end{array}$ & 4,33 & 4,50 & 4,42 & $\begin{array}{l}\text { Sangat } \\
\text { Baik }\end{array}$ \\
2 & $\begin{array}{l}\text { Isi Materi } \\
\text { (Konten) }\end{array}$ & 3,80 & 4,40 & 4,10 & $\begin{array}{l}\text { Sangat } \\
\text { Baik }\end{array}$ \\
3 & $\begin{array}{l}\text { Bahasa dan } \\
\text { Komunikasi }\end{array}$ & 4,67 & 4,50 & 4,58 & $\begin{array}{l}\text { Sangat } \\
\text { Baik }\end{array}$ \\
4 & $\begin{array}{l}\text { Pemanfaatan } \\
\text { Media }\end{array}$ & 4,00 & 4,00 & 4,00 & Baik \\
5 & $\begin{array}{l}\text { Penyajian/ } \\
\text { Presentasi } \\
\text { Rerata }\end{array}$ & 4,00 & 4,17 & 4,08 & $\begin{array}{l}\text { Sangat } \\
\text { Baik } \\
\text { Sangat }\end{array}$ \\
\hline
\end{tabular}

Sumber: Hasil pengolahan data primer

Berdasarkan penilaian ahli materi 1 terhadap seluruh indikator yang divalidasi diperoleh skor rata-rata 4,19 dengan kategori "sangat baik" dan dinyatakan layak diujikan untuk tahap selanjutnya. Penilaian ahli materi 2 terhadap seluruh indikator yang divalidasi diperoleh skor rata-rata 4,33 dengan kategori "sangat baik".

Aspek yang dinilai oleh ahli media dalam uji alpha berjumlah 9 aspek yang keseluruhannya berjumlah 38 indikator. Kedua ahli media memberikan saran dan komentar serta rekomendasi untuk perbaikan media. Penilaian ahli media ditunjukkan pada Tabel 4.

Berdasarkan penilaian ahli media 1 terhadap seluruh indikator yang divalidasi diperoleh skor rata-rata 4,45 dengan kategori "sangat baik" dan dinyatakan layak 
diujikan untuk tahap selanjutnya. Penilaian ahli media 2 terhadap seluruh indikator yang divalidasi diperoleh skor rata-rata 4,03 dengan kategori "sangat baik" dan dinyatakan layak untuk diujikan pada tahap selanjutnya.

Tabel 4. Rerata Skor Hasil Validasi Ahli Media

\begin{tabular}{|c|c|c|c|c|c|}
\hline \multirow[t]{2}{*}{ No } & \multirow[t]{2}{*}{ Aspek } & \multicolumn{2}{|c|}{$\begin{array}{l}\text { Ahli } \\
\text { Materi }\end{array}$} & \multirow[t]{2}{*}{ Rerata } & \multirow[t]{2}{*}{$\begin{array}{l}\text { Kriteri } \\
\text { a }\end{array}$} \\
\hline & & 1 & 2 & & \\
\hline 1 & $\begin{array}{l}\text { Informasi } \\
\text { Tambahan }\end{array}$ & 4,67 & 4,00 & 4,33 & $\begin{array}{c}\text { Sangat } \\
\text { Baik }\end{array}$ \\
\hline 2 & $\begin{array}{l}\text { Perhitungan } \\
\text { Afektif }\end{array}$ & 4,00 & 5,00 & 4,50 & $\begin{array}{l}\text { Sangat } \\
\text { Baik }\end{array}$ \\
\hline 3 & $\begin{array}{l}\text { Tampilan } \\
\text { Antarmuka }\end{array}$ & 4,57 & 4,29 & 4,43 & $\begin{array}{l}\text { Sangat } \\
\text { Baik }\end{array}$ \\
\hline 4 & Navigasi & 4,00 & 4,33 & 4,17 & $\begin{array}{l}\text { Sangat } \\
\text { Baik }\end{array}$ \\
\hline 5 & Pedagogi & 4,30 & 4,10 & 4,20 & $\begin{array}{c}\text { Sangat } \\
\text { Baik }\end{array}$ \\
\hline 6 & $\begin{array}{l}\text { Fitur yang } \\
\text { Tidak Terlihat }\end{array}$ & 4,67 & 3,67 & 4,17 & $\begin{array}{l}\text { Sangat } \\
\text { Baik }\end{array}$ \\
\hline 7 & $\begin{array}{l}\text { Ketahanan } \\
\text { Program }\end{array}$ & 4,00 & 4,00 & 4,00 & Baik \\
\hline 8 & $\begin{array}{l}\text { Materi } \\
\text { Tambahan }\end{array}$ & 4,00 & 3,00 & 3,50 & Baik \\
\hline 9 & $\begin{array}{l}\text { Prinsip e- } \\
\text { learning }\end{array}$ & 5,00 & 3,83 & 4,42 & Baik \\
\hline & Rerata & 4,36 & 4,02 & 4,19 & $\begin{array}{c}\text { Sangat } \\
\text { Baik }\end{array}$ \\
\hline
\end{tabular}

Sumber: Hasil pengolahan data primer

Uji beta merupakan tes akhir yang sepenuhnya dilakukan oleh peserta didik sebagai peserta uji coba. Uji beta dilakukan secara formal dengan prosedur pembelajaran yang telah disepakati pada rencana pelaksanaan pembelajaran. Uji beta dilakukan secara bertahap sebanyak 4 kali pertemuan. Peserta didik yang melakukan uji beta berjumlah 32 yang keseluruhannya merupakan peserta didik kelas X.1 SMA Assalam Sukoharjo. Berdasarkan hasil rekapitulasi data uji beta terhadap e-learning mata pelajaran Geografi, diperoleh skor rata-rata 4,5 dengan kategori "sangat baik" dan dinyatakan layak untuk digunakan dalam proses pem- belajaran geografi materi Mitigasi dan Adaptasi Bencana Alam. Hasil uji beta ditunjukkan Tabel 5.

Tabel 5. Rerata Skor Hasil Validasi Uji Beta

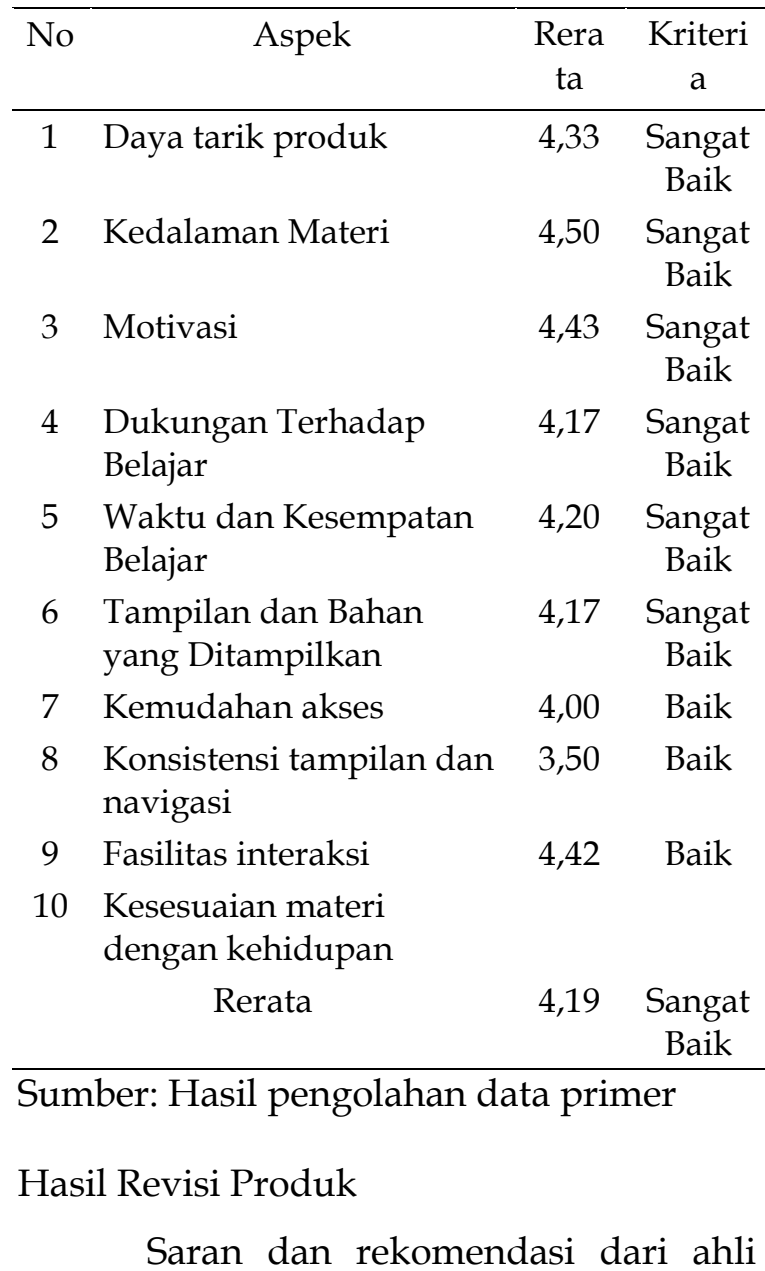
materi dibutuhkan untuk memperbaiki kualitas materi yang akan disajikan dalam $e$ earning mata pelajaran Geografi. Saran dan rekomendasi dijadikan panduan bagi pengembang untuk melakukan revisi terhadap materi e-learning. Ahli materi memberikan saran agar menambahkan referensi dengan sumber yang terkini atau up to date. Referensi yang dimaksud adalah menambahkan contoh-contoh konkrit dari materi yang terjadi dan terkini. Misalnya contohcontoh bencana yang telah terjadi di Indonesia dalam waktu dekat ini. Selain menambahkan contoh-contoh tersebut, ahli materi juga menyarankan agar menggunakan referensi buku yang terbaru. Setelah menerima saran dari ahli materi, pengembang lang- 
sung merevisi dengan menambahkan referensi-referensi terkini untuk melengkapi materi dalam e-learning. Beberapa saran dan rekomendasi dari ahli materi adalah menambah referensi dengan sumber yang up to date, perlu kesesuaian antara materi dengan sumber, menambahkan diagram alir keterkaitan mitigasi dengan kesiapsiagaan, respon dan pemulihan, dan menambahkan contoh peta kebencanaan seperti peta rawan bencana, peta kerentanan bencana dan peta risiko bencana.

Saran dari ahli media untuk perbaikan yaitu melakukan perbaikan pada deskripsi mata pelajaran, menambah materi pada pertemuan pertama, memperbaiki tampilan quiz menjadi 5 soal per halaman, dan memperbaiki deskripsi pada setiap tugas.

Saran dari pengguna e-learning sangat diperlukan untuk memperbaiki kualitas e-learning mata pelajaran Geografi agar sesuai dengan keinginan calon pengguna $e$ learning. Tidak banyak saran atau masukkan dari calon pengguna e-learning, hanya ada beberapa masukkan yaitu pengguna e-learning menghendaki konten ditambah untuk pokok bahasan lainnya pada mata pelajaran Geografi dan menghendaki e-learning dikembangkan untuk mata pelajaran lainnya.

\section{Hasil Uji Coba Produk}

Untuk mengetahui keefektifan penggunaan e-learning mata pelajaran Geografi, maka dilakukan penilaian terhadap hasil belajar dan kemandirian belajar peserta didik dalam uji beta.

Data hasil uji coba lapangan untuk menilai hasil belajar yang dilakukan di seko-lah dengan memberikan pretest dan posttest pada dua kelas yang berbeda, yaitu pada kelas eksperimen dan kelas kontrol. Kelas kontrol yang digunakan adalah kelas X2 dan kelas eksperimen pada kelas X1. Kelas X1 merupakan kelas yang digunakan dalam uji beta. Peneliti menggunakan kelas yang digunakan untuk uji beta sekaligus untuk dijadikan sebagai kelas eksperimen berdasarkan hasil brainstorming dengan pen- didik geografi yang bersangkutan. Data yang digunakan dalam menguji hipotesis ini adalah skor $N$-gain kelompok eksperimen dan kelompok kontrol. Rekapitulasi hasil pretest, posttest dan $N$-gain kelas eksperimen dan kelas kontrol ditunjukkan Tabel 6.

Tabel 6. Rekapitulasi Hasil Pretest, Posttest dan N-gain Kelas Eksperimen dan Kelas Kontrol

\begin{tabular}{|c|c|c|c|}
\hline & & \multicolumn{2}{|c|}{ Kelas } \\
\hline & & Eksperimen & Kontrol \\
\hline \multirow[t]{3}{*}{ Pretest } & Minimum & 44 & 48 \\
\hline & Maksimum & 68 & 68 \\
\hline & Rerata & 55,25 & 57,90 \\
\hline \multirow[t]{3}{*}{ Posttest } & Minimum & 76 & 72 \\
\hline & Maksimum & 96 & 92 \\
\hline & Rerata & 85,88 & 81,90 \\
\hline \multirow[t]{3}{*}{ N-gain } & Minimum & 0,45 & 0,30 \\
\hline & Maksimum & 0,89 & 0,78 \\
\hline & Rerata & 0,68 & 0,57 \\
\hline \multirow{4}{*}{$\begin{array}{l}\text { Frekuensi } \\
\text { Kriteria } \\
N \text {-gain }\end{array}$} & Tinggi & $14(43,75 \%)$ & $3(14,29 \%)$ \\
\hline & Sedang & $18(56,25 \%)$ & $17(80,95 \%)$ \\
\hline & Rendah & $0(0 \%)$ & $1(4.76 \%)$ \\
\hline & Total & $32(100 \%)$ & $21(100 \%)$ \\
\hline
\end{tabular}

Sumber: Hasil pengolahan data primer

Uji normalitas data $N$-gain pretest posttest kelas eksperimen dan kelas kontrol disajikan pada Tabel 7.

Berdasarkan hasil uji normalitas data $N$-gain diperoleh nilai $\mathrm{p}>0,05$ yaitu kelas eksperimen sebesar 0,200 dan kelas kontrol sebesar 0,200 sehingga kedua data tersebut berdistribusi normal.

Tabel 7. Hasil Uji Normalitas Skor N-Gain Pretest Posttest Kelas Eksperimen dan Kelas Kontrol

\begin{tabular}{lcccc}
\hline \multicolumn{1}{c}{ Kelas } & \multicolumn{3}{c}{ Kolmogorov-Smirnova } & Keterangan \\
& Statistic & df & $\mathrm{p}$ & \\
\hline Eksperimen & 0,102 & 21 & 0,200 & Normal \\
Kontrol & 0,107 & 21 & 0,200 & Normal \\
\hline
\end{tabular}

Sumber: Hasil olah data statistik

Uji homogenitas data pretest dan posttest kelas eksperimen dan kelas kontol disajikan pada Tabel 8. 
Tabel 8. Hasil Uji Homogenitas Skor NGain Pretest Posttest Kelas Eksperimen dan Kelas Kontrol

\begin{tabular}{ccccc}
\hline $\begin{array}{c}\text { Levene } \\
\text { Statistic }\end{array}$ & df1 & df2 & p & Keterangan \\
\hline 0,653 & 1 & 51 & 0,423 & Homogen \\
\hline
\end{tabular}

Sumber: Hasil olah data statistik

Hasil uji homogenitas Skor N-Gain pretest posttest Kelas eksperimen dan kelas kontrol menunjukkan bahwa $\mathrm{p}>$ (a) 0,05 dan dapat disimpulkan bahwa data $N$-gain pretest posttest kelas eksperimen dan kelas kontrol berasal dari varian yang homogen.

Setelah diketahui data $N$-gain pretest posttest kelas eksperimen dan kelas kontrol berdistribusi normal dan berasal dari varian yang homogen, langkah selanjutnya adalah melakukan uji independent sample t test pada SPSS terhadap $N$-gain pretest posttest kelas eksperimen dan kelas kontrol untuk membuktikan hipotesis. Hasil uji beta disajikan pada Tabel 9.

Tabel 9. Hasil Uji Perbedaan Skor N-gain Pretest Posttest Kelas Eksperimen dan Kelas Kontrol

\begin{tabular}{llccc}
\hline & & \multicolumn{3}{c}{$\begin{array}{c}\text { t-test for Equality of } \\
\text { Means }\end{array}$} \\
\hline N-gain & $\begin{array}{l}\text { Equal variances } \\
\text { assumed }\end{array}$ & 3,689 & 51 & 0,001 \\
$\begin{array}{l}\text { Equal variances } \\
\text { not assumed }\end{array}$ & 3,597 & 39,245 & 0,001 \\
\hline
\end{tabular}

Sumber: Hasil olah data statistik

Berdasarkan uji menggunakan independent sample $t$ test pada SPSS yang selanjutnya diuji signifikansinya dengan menggunakan taraf signifikasi sebesar 5\% diperoleh nilai $\mathrm{p}=0,001$ dan dapat disimpulkan $\mathrm{H}_{0}$ ditolak atau rerata skor $N$-gain pretest dan posttest peserta didik pada kelas eksperimen dan kelas kontrol adalah berbeda.

Berdasarkan Tabel 6 dapat dilihat nilai maksimum, nilai minimum dan rerata $N$-gain pretest posttest kelas eksperimen lebih tinggi dibandingkan dengan kelas kontrol. Nilai minimum pada kelas eksperimen ada- lah 0,45 sedangkan pada kelas kontrol adalah 0,30 . Nilai maksimum pada kelas eksperimen adalah 0,89 sedangkan pada kelas kontrol adalah 0,78. Kemudian rerata $\mathrm{N}$-gain pada kelas kontrol adalah 0,57 sedangkan pada kelas eksperimen adalah 0,68 dan dapat dikatakan bahwa $\mathrm{N}$-gain kelas eksperimen lebih tinggi dibandingkan dengan $N$ gain kelas kontrol. Hal ini menunjukkan $e$ learning mata pelajaran Geografi dapat dikatakan efektif untuk digunakan dalam pembelajaran.

Kemandirian belajar peserta didik diperoleh dengan melakukan analisis terhadap angket pre dan post pada dua kelas yang berbeda, yaitu pada kelas eksperimen dan kelas kontrol. Rekapitulasi hasil $\mathrm{N}$-gain kelas eksperimen dan kelas kontrol disajikan pada Tabel 10.

Tabel 10. Rekapitulasi Hasil N-gain Kemandirian Belajar Kelas Eksperimen dan Kelas Kontrol

\begin{tabular}{llcc}
\hline & & \multicolumn{2}{c}{ Kelas } \\
\cline { 3 - 4 } & & Eksperimen & Kontrol \\
\hline N-gain & Minimum & 0,31 & 0,09 \\
& Maksimum & 0,81 & 0,47 \\
& Rerata & 0,44 & 0,21 \\
Frekuensi & Tinggi & $3(9,38 \%)$ & $0(0 \%)$ \\
Kriteria & Sedang & $29(90,63 \%)$ & $3(14,29 \%)$ \\
N-gain & Rendah & $0(0 \%)$ & $18(85,71 \%)$ \\
& Total & $32(100 \%)$ & $21(100 \%)$ \\
\hline
\end{tabular}

Sumber: Hasil pengolahan data primer

Uji normalitas data $\mathrm{N}$-gain pretest posttest kelas eksperimen dan kelas kontrol disajikan pada Tabel 11.

Tabel 11. Hasil Uji Normalitas Skor N-Gain Kemandirian Belajar Kelas Eksperimen dan Kelas Kontrol

\begin{tabular}{lcccl}
\hline \multirow{1}{*}{ Kelas } & \multicolumn{3}{c}{ Kolmogorov-Smirnov ${ }^{\text {a }}$} & Keterangan \\
& Statistic & df & p & \\
\hline Eksperimen & 0,162 & 21 & 0,158 & Normal \\
Kontrol & 0,186 & 21 & 0,056 & Normal \\
\hline
\end{tabular}

Sumber: Hasil olah data statistik

Berdasarkan hasil uji normalitas data $N$-gain kemandirian belajar diperoleh 
nilai $p>0,05$ yaitu kelas eksperimen sebesar 0,158 dan kelas kontrol sebesar 0,056 sehingga kedua data tersebut berdistribusi normal.

Uji homogenitas data pretest dan posttest kelas eksperimen dan kelas kontol disajikan pada Tabel 12.

Tabel 12. Hasil Uji Homogenitas Skor NGain Kemandirian Belajar Kelas Eksperimen dan Kelas kontrol

\begin{tabular}{ccccc}
\hline $\begin{array}{c}\text { Levene } \\
\text { Statistic }\end{array}$ & df1 & df2 & p & Keterangan \\
\hline 0,653 & 1 & 51 & 0.315 & Homogen \\
\hline
\end{tabular}

Sumber: Hasil olah data statistik

Hasil uji homogenitas Skor N-Gain kemandirian belajar kelas eksperimen dan kelas kontrol menunjukkan bahwa $\mathrm{p}>$ (a) 0,05 dan dapat disimpulkan bahwa data $N$ gain kemandirian belajar kelas eksperimen dan kelas kontrol berasal dari varian yang homogen.

Setelah diketahui data $N$-gain kemandirian belajar kelas eksperimen dan kelas kontrol berdistribusi normal dan berasal dari varian yang homogen, langkah selajutnya adalah melakukan uji independent sample $t$ test pada SPSS terhadap $N$-gain kemandirian belajar kelas kontrol dan kelas eksperimen untuk membuktikan hipotesis. Hasil uji beda ditunjukkan Tabel 13 .

Tabel 13.Hasil Uji Perbedaan Skor N-gain Pretest Posttest Kelas Eksperimen dan Kelas Kontrol

\begin{tabular}{llccc}
\hline & & \multicolumn{3}{c}{-test for Equality of } \\
Means & $\mathrm{df}$ & $\mathrm{p}$ \\
\hline N-gain & $\begin{array}{l}\text { Equal variances } \\
\text { assumed }\end{array}$ & 7,709 & 51 & 0,000 \\
& $\begin{array}{l}\text { Equal variances } \\
\text { not assumed }\end{array}$ & 8,251 & 50,535 & 0,000 \\
\hline
\end{tabular}

Sumber: Hasil olah data statistik

Berdasarkan uji menggunakan independent sample t test pada SPSS yang selanjutnya diuji signifikansinya dengan menggunakan taraf signifikasi sebesar 5\% diper- oleh nilai $\mathrm{p}=0,000$ dan dapat disimpulkan $\mathrm{H}_{0}$ ditolak atau rerata skor $\mathrm{N}$-gain kemandirian belajar peserta didik sebelum dan setelah pembelajaran pada kelas eksperimen dan kelas kontrol adalah berbeda.

Berdasarkan Tabel 10 dapat dilihat nilai maksimum, nilai minimum dan rerata $\mathrm{N}$-gain kemandirian belajar kelas eksperimen lebih tinggi dibandingkan dengan kelas kontrol. Nilai minimum pada kelas eksperimen adalah 0,31 sedangkan pada kelas kontrol adalah 0,09. Nilai maksimum pada kelas eksperimen adalah 0,81 sedangkan pada kelas kontrol adalah 0,47. Kemudian rerata $N$-gain pada kelas kontrol adalah 0,44 atau dalam kriteria sedang sedangkan pada kelas eksperimen adalah 0,21 atau dalam kriteria rendah dan dapat dikatakan bahwa $N$-gain kelas eksperimen lebih tinggi dibandingkan dengan $\mathrm{N}$-gain kelas kontrol. Hal ini menunjukkan e-learning mata pelajaran Geografi dapat dikatakan efektif dalam meningkatkan kemandirian belajar peserta didik.

\section{Simpulan}

Berdasarkan hasil penelitian dan pembahasan yang telah disampaikan, maka dapat disimpulkan sebagai berikut. Kelayakan produk e-learning berdasarkan hasil uji alpha oleh ahli materi 1 terhadap seluruh indikator yang divalidasi diperoleh skor rata-rata 4,19 dengan kategori "sangat baik" dan validasi oleh ahli materi 2 terhadap seluruh indikator yang divalidasi diperoleh skor rata-rata 4,33 dengan kategori "sangat baik". Kelayakan produk e-learning berdasarkan hasil uji alpha oleh ahli media 1 terhadap seluruh indikator yang divalidasi diperoleh skor rata-rata 4,19 dengan kategori "sangat baik" dan validasi oleh ahli media 2 terhadap seluruh indikator yang divalidasi diperoleh skor rata-rata 4,03 dengan kategori "sangat baik". Hasil penilaian pengguna e-learning oleh peserta didik diperoleh skor rata-rata 4,5 dengan kategori "sangat baik".

Terdapat perbedaan hasil belajar antara kelas eksperimen dan kelas kontrol 
setelah pembelajaran dengan nilai $\mathrm{p}=0,001$. Rerata $N$-gain pada kelas kontrol adalah 0,57 sedangkan pada kelas eksperimen adalah 0,68 dan dapat dikatakan bahwa $N$-gain kelas eksperimen lebih tinggi dibandingkan dengan $N$-gain kelas kontrol.

Terdapat perbedaan kemandirian belajar antara kelas eksperimen dan kelas kontrol setelah pembelajaran dengan nilai $\mathrm{p}$ $=0,000$. Rerata $N$-gain kemandirian belajar pada kelas kontrol adalah 0,44 atau dalam kriteria sedang sedangkan pada kelas eksperimen adalah 0,21 atau dalam kriteria rendah dan dapat dikatakan bahwa $N$-gain kelas eksperimen lebih tinggi dibandingkan dengan $N$-gain kelas kontrol.

Berdasarkan hasil penelitian yang sudah disajikan dapat disarankan hal-hal sebagai berikut: (1) e-learning mata pelajaran ini perlu implementasi lebih lanjut agar diketahui kelemahan dan kekurangannya dalam proses pembelajaran, (2) materi geografi yang ada pada e-learning perlu ditambahkan agar pembelajaran dalam satu semester atau satu tahun pembelajaran bisa dibantu secara menyeluruh melalui e-learning, (3) materi yang disajikan di e-learning tidak hanya mata pelajaran Geografi tetapi mata pelajaran lainnya, (4) pendidik diharapkan mampu memanfaatkan e-learning ini sebagai alternatif dalam meningkatkan hasil belajar dan kemandirian belajar peserta didik, dan (5) Bagi para pendidik yang memiliki keterbatasan waktu dalam mengajar, e-learning dapat dijadikan alternatif untuk mengatasi alokasi waktu yang terbatas.

\section{Daftar Pustaka}

Alessi, S. M., \& Trollip, S. P. (2001). Multimedia for learning: methods and development (3rd ed.). Boston: Allyn and Bacon.

Amandu, G. M., Muliira, J. K., \& Fronda, D. C. (2013). Using moodle e-learning platform to foster student self-directed learning: experiences with utilization of the Software in undergraduate nursing courses in a middle Eastern University. Procedia - Social and
Behavioral Sciences, 93, 677-683.

https://doi.org/10.1016/j.sbspro.2013 .09 .260

BSNP. (2006). Standar kompetensi dan kompetensi dasar SMA/MA. Jakarta: Badan Standar Nasional Pendidikan.

Costa, C., Alvelos, H., \& Teixeira, L. (2012). The use of moodle e-learning platform: a study in a Portuguese University. Procedia Technology, 5, 334343.

https:// doi.org/10.1016/j.protcy.2012 .09 .037

Hubbard, P., Bartley, B., Fuller, D., \& Kitchin, R. (2005). Thinking geographically: space, theory and contemporary human geography. Londom: Continuum.

Januszewski, A., \& Molenda, M. (2008). Educational technology: a definition with commentary. New York: Lawrence Erlbaum Associates.

Meltzer, D. E. (2012). The reliationship between mathematics preparation and conceptual learning gains in physics: A possible "Hidden Variable" in Diagnostic Pretest Scores. . American Journal of Physics, 70(12), 1259-1268.

Prawiradilaga, D. S., Ariani, D., \& Handoko, H. (2013). Mozaik teknologi pendidikan e-learning. Jakarta: Kencana Prenada Media Group.

Sara, K., \& Mukminan, M. (2014). Pengembangan e-learning mata kuliah aplikasi komputer 2 di program studi pendidikan sejarah Universitas Flores. Jurnal Inovasi Teknologi Pendidikan, 1(2). Retrieved from https://journal.uny.ac.id/index.php/ jitp/article/view/2525

Sari, M., \& Apriani, J. (2014). Pengaruh model pembelajaran concept attaiment terhadap hasil belajar siswa kelas viii pada konsep sistem pernapasan (studi eksperimen di smpn 2 gunung sahilan tp. 
2013/2014). Bio Lectura, 1(2), 136-144.

Seels, B. B., \& Richey, R. C. (1994).

Instructional technology: the definition and domains of the field. Washington DC: AECT.

Shishkovskaya, J., Bakalo, D., \& Grigoryev, A. (2015). EFL Teaching in the Elearning environment: updated principles and methods. Procedia Social and Behavioral Sciences, 206, 199 204.

https://doi.org/10.1016/j.sbspro.2015 .10 .007

Sudijono, A. (2013). Pengantar evaluasi pendidikan. Jakarta: PT Rajagrafindo Persada. 